\title{
What Lies Beneath: The Political Roots of State Merit Systems
}

\author{
Anirudh V. S. Ruhil \\ University of Illinois at Chicago \\ Pedro J. Camões \\ Universidade do Minho
}

\section{ABSTRACT}

The history of the rise and diffusion of the merit principle in American government is common lore to students of public administration and political science. Several descriptive accounts notwithstanding, scholars have ignored an intriguing puzzle vis-à-vis state merit adoptions: Why did some states adopt merit systems early in the twentieth century while other states followed suit decades later, and then only when they were forced to do so by the federal government? When we analyze state merit adoptions that occurred between 1900 and 1939 we find nationwide and state-specific demographic, economic, structural, and political factors-for example, growth in patronage constituencies; the use of the Australian ballot; political party competition; dwindling patronage resources post-Pendleton; and the onset of the Great Depression-that shifted politicians' preferences for the merit principle rather than patronage. Our research thus breaks sharply with the extant literature by emphasizing the political undercurrents of merit reform.

\section{STATE MERIT REFORM: AN ENIGMA}

The history of the rise and diffusion of the merit principle in American government is common lore to students of public administration and political science. Most textbook accounts of this period of American political development, for example, cover such historical events as Garfield's assassination, the efforts of early stalwarts such as Curtis, Jenckes, and Sumner in instigating personnel reform, passage of the Pendleton Act in 1883, and stuttering state-local adoptions of mini-Pendleton Acts (see, for example, Adrian and Fine 1991; Dye 2000; Gray and Eisinger 1997). In particular, the literature on merit reform is replete with excellent descriptive accounts of the history surrounding the birth and spread of the merit principle in the United States (see, for example, Hoogenboom 1968; Van Riper 1958). However, while some scholars, notably Johnson and Libecap (1994), have studied federal adoption of the merit principle, students of American political development, state politics, and bureaucracy have virtually ignored an intriguing puzzle vis-à-vis state merit adoption: Why

This article has benefited from the constructive criticism offered by Melissa J. Marschall, Scott Hays, Silvia Mendes, Dennis Dresang, and an anonymous referee. Pedro J. Camões acknowledges the Universidade do Minho and the Fundação para a Ciência e Tecnologia's financial support while on leave at the University of South Carolina. 
did some states adopt merit systems early in the twentieth century while other states did so decades later?

Consequently, in this study we make one of the first rigorous empirical investigations of the state merit reform by undertaking a theoretically motivated event history analysis of state merit adoptions that occurred between 1900 and 1939. ${ }^{1}$ Drawing upon institutional and public-choice arguments, we highlight the relevance of nationwide and state-specific demographic, economic, structural, and political factors - for example, growth in patronage constituencies; the use of the Australian ballot; political party competition; dwindling patronage resources post-Pendleton; and the onset of the Great Depression-in the shift of politicians' preferences from patronage to the merit system. Our research thus breaks sharply with the extant literature by emphasizing the political undercurrents of merit reform.

While the good government sentiment that marked the Progressive Era no doubt gave rise to the merit principle per se, we believe conventional explanations of reform ascribe an unduly deterministic influence to political culture and good government arguments. Because historians agree that the Progressive movement was all but over by the time of the First World War, it is difficult to understand how and why Progressive forces drove adoptions in the late 1930s, the decade in which the majority of the states established merit systems.

In this study, we demonstrate that a political calculus internal to the states themselves drove adoptions. Specifically, we argue that in adopting merit systems state politicians were responding to socioeconomic changes that increased the costs associated with patronage and thereby reduced the net electoral benefits of spoils politics. In brief, then, conventional textbook accounts (of federal merit-system adoptions) that emphasize the good government thesis not only ignore the political dynamics of reform but also fail to understand how the process of adoption diffused across the American states. As such, we believe extant research misrepresents an important phase in state-level personnel reform.

We initiate our argument with a brief overview of conventional accounts of state merit adoptions. Thereafter we set forth our theoretical framework and analytic strategy, and then we discuss our empirical results. In conclusion, we emphasize our fundamental contribution to the study of personnel reform in the American states: an explication of the politics that underlie state merit systems.

\section{A BRIEF HISTORY OF THE MERIT SYSTEM IN AMERICA}

For much of the nineteenth century the spoils system dominated personnel policy in American government, largely because politicians recognized the benefits associated with staffing public offices with loyal individuals of the same political persuasion. In particular, politicians deemed a forced alliance of interests to be necessary if executives were to implement their pet policies and programs in the face of legislative resistance (Schultz and Maranto 1998; Maranto 1998; Van Riper 1958; Lambert 1885). Consequently, technical expertise, training, and competence did not guide recruitment, retention, or promotion of civil servants. Rather, party loyalty, as reflected through contributions to party coffers and service to the party, was the overriding criterion for securing public employment (Van Riper 1958).

While the earliest stirrings of the personnel reform movement surfaced in the $1850 \mathrm{~s}$, a

1 In subsequent sections, we explain why we restrict our analytic focus to the period between 1900 and 1939. 
meaningful start to civil service reform did not come about until the mid-1860s (S. H. Aronson 1964). Republican members of Congress Sumner (in 1864) and Jenckes (in 1865) were the first to introduce civil service legislation in Congress. ${ }^{2}$ After the Civil War ended, and because of the protracted struggle between President Johnson and the Republican Congress over control of patronage, the civil service reform question gathered steam (Hoogenboom 1968). It was only a matter of time until the first piece of civil service legislation, authored by Jenckes, passed in 1871. This bill established a seven-member Civil Service Commission and accorded to it the task of formulating appropriate rules and regulations for initiating meaningful personnel reform of the federal bureaucracy (Fish 1920).

George William Curtis, a Republican with Puritan roots, served as the head of the National Civil Service Commission from 1871 until 1875, when lapsed appropriations rendered the commission useless. From this post he went on to become the president of the New York Civil Service Reform Association (established in 1877), and in 1881 he established the National Civil Service Reform League (Fish 1920). By 1880, the New York Civil Service Reform Association counted among its 583 members influential persons from roughly thirty-three states and territories (Stewart 1929). Working in unison the National Civil Service Reform League and the New York Civil Service Reform Association published several pamphlets and monographs that trumpeted the need for, and benefits of, civil service reform (Van Riper 1958, p. 78). By some accounts Curtis' stewardship attracted to the reform movement individuals from the top strata of politics, law, business, journalism, and education, all apparently driven by a desire to maintain liberty and sustain democracy (see for example, Van Riper 1958; Schultz and Maranto 1998; Maranto 1998; and Hoogenboom 1958-59 and 1968). Fish (1920, p. 245), however, suggests that the reformers were driven as much by the desire to introduce business practices into government as they were by loftier goals, such as honest government. ${ }^{3}$

In its initial stages the civil service reform movement drew bipartisan support both in Congress and in the few states that had begun to move in the direction of implementing personnel reform in the state machinery (Barrilleaux 1999). Given the strong proreform sentiment in the nation and in many states during the 1870 s, it was not altogether surprising, then, that the issue of further personnel reform featured centrally in the mid-term election of 1882 (Van Riper 1958, p. 92). Garfield's assassination by a disappointed office seeker helped to elevate the issue onto the public agenda. Moreover, the poor showing of the Republicans in the mid-term elections saw the small group of hitherto recalcitrant Republican congressmen capitulate: the specter of almost certain Democratic victory in 1884 and the fear of seeing their Republican supporters replaced by Democrats was a powerful goad. Consequently, Congress hurriedly passed the Pendleton Civil Service Act on January 16, 1883, writing into law a model bill that had been drafted by the New York Civil Service Reform Association a year earlier.

In sum, the Pendleton Act brought to the United States "a merit system founded on British precedents: that is, a system of civil service requirements and organization based on (1) competitive examinations, (2) relative security of tenure, and (3) political neutrality" (Van Riper 1958, p. 100). The Act provided for the establishment of a bipartisan commission of three full-time members appointed for indefinite terms. While the Act covered the

2 Both Sumner (R-MA) and Jenckes (R-RI), respectively, were persistent in their efforts, introducing a series of civil service reform bills aimed at eradicating patronage via the implementation of modern merit systems in government (Van Riper 1958, p. 65).

3 See also Stewart (1929). 


\section{Figure 1}

State Adoption of Merit Systems, 1883-1940

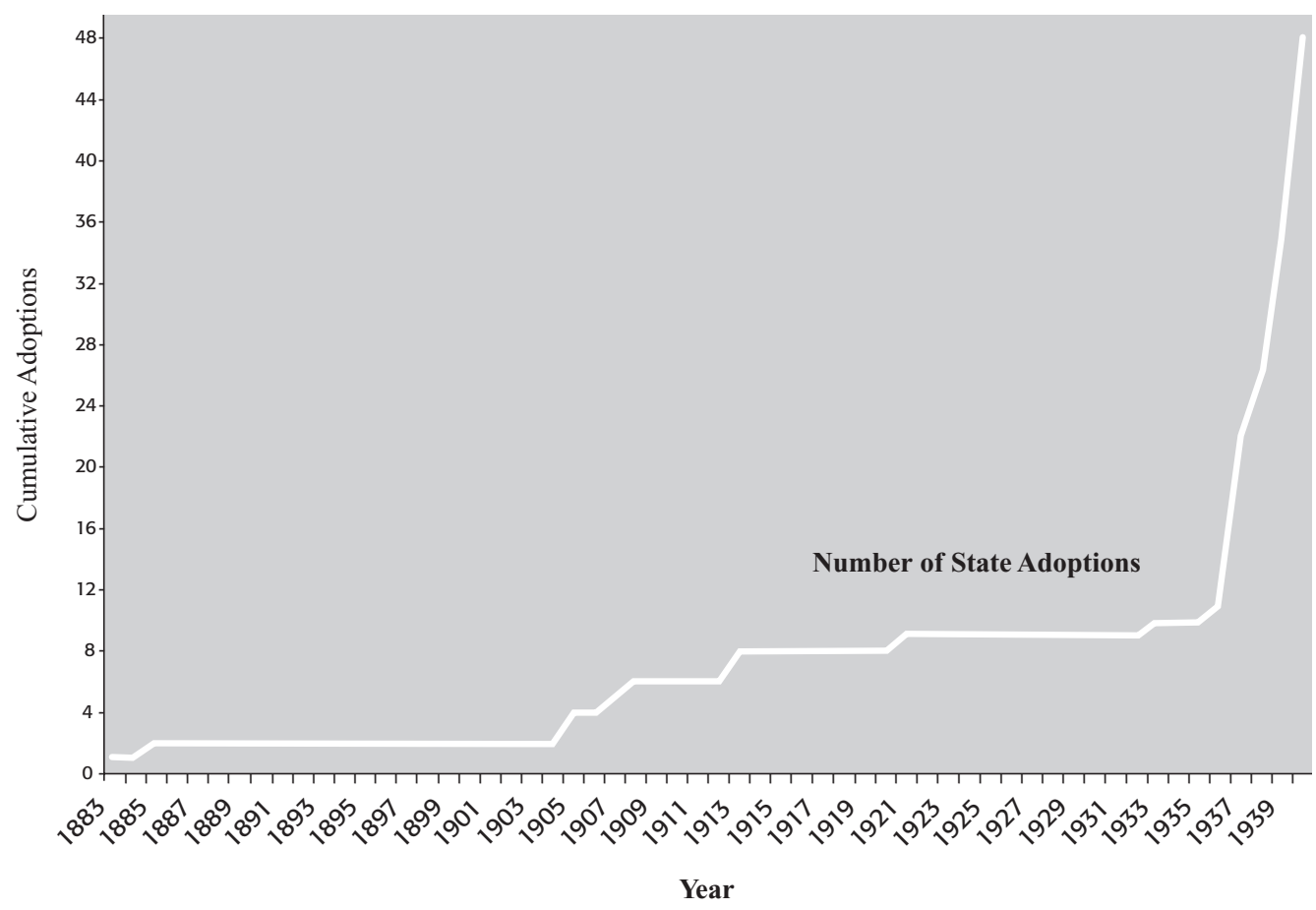

majority of the offices in the executive branch, it exempted officers appointed by the president, as well as the employees of the legislative and judicial branches. ${ }^{4}$

\section{CIVIL SERVICE REFORM IN THE STATES}

The Pendleton Civil Service Act is widely believed to have provided a model for state governments to emulate when they considered a merit-based state personnel system. Yet what is less recognized is that the Pendleton Act was itself closely based on a model act drafted by the New York Civil Service Reform Association. ${ }^{5}$ Shortly after passage of the Pendleton Act, the state of Massachusetts, whose reform association members had close ties with their colleagues in New York, drafted and adopted their own merit system. ${ }^{6}$ For the next two decades, there was virtually no activity on the state civil service reform front. It was not until 1905, when both Illinois and Wisconsin legislated a merit system for state government employees, that civil service reform reemerged. A few other states followed suit: Colorado (1907), New Jersey (1908), California (1913), Ohio (1913), and Maryland (1921). To be sure, as Figure 1 makes clear, the diffusion of the merit principle across the state governments was anything but rapid.

4 See Baruch (1942) for details of the personnel practices instituted by the Civil Service Commission.

5 This fact, together with New York's decision to pass a civil service law in the same year as Pendleton, offers an unusual example of a policy that diffuses both horizontally and vertically, albeit from the bottom up.

6 The literature reflects some confusion over the exact date of Massachusetts' merit system adoption-1884 and 1885. See, for example, Devlin (1896). 
In the late 1930s, merit reform surfaced for a third time since passage of the Pendleton Act. Some argue that this bout of reformism was, at least to some extent, driven by the 1939 amendment to the Social Security Act of 1935 (see A. H. Aronson 1974; Cayer 1986; Dresang 1982). The 1939 amendment essentially required that every state receiving Social Security monies place its unemployment security and public assistance employees under the civil service by January 1, 1940, or forgo the Social Security funds altogether. If this amendment forced recalcitrant states to adopt merit systems, we ought to see the bulk of tardy adoptions occurring in 1940. However, almost 68 percent (twenty-four) of the remaining thirty-seven states established merit systems between 1936 and 1939. This suggests that unless the states foresaw the 1939 SSA Amendment (a highly improbable event) and hence responded preemptively, some other causal processes must have been responsible for these post-1935 adoptions. We believe that a political dynamic internal to the states was largely responsible for the general pattern of state merit activity. Not only has extant research on state merit reforms ignored the political dimensions of state merit reform, it has failed to specify and test causal hypotheses about the rise and diffusion of the merit principal across the American states.

\section{THE NEED FOR A FRESH LOOK AT STATE MERIT ADOPTIONS}

Given that the civil service system marks a pivotal development in the governmental history of the United States, the lack of empirical studies of state merit systems is rather surprising. To be sure, the literature on merit systems does not want for normative or descriptive studies of the impact of the merit system (see, for example, Conover 1925; Anderson and Weidner 1951; Graves 1953). Further, virtually all scholars note that states established merit systems soon after the Pendleton Act introduced the merit system into federal government in 1883 (see Rosenbloom 1989; Hays and Reeves 1984). Scholars also suggest that states implemented the merit principle under pressure from the Progressive Era reformers and good government groups who sought governmental efficiency and to put an end to the source of governmental inefficiency-machine politics (see Cayer 1995; Schultz and Maranto 1998). However, two facts call into question the validity of the good government thesis.

First, we now know that mobilizing and maintaining an interest group is an extremely difficult task, especially in the absence of selective incentives (see Olson 1965). The reformers could neither rely on selective, purposive benefits to mobilize the lay citizenry nor could they avail of the organizational benefits of a federated structure. Second, historians commonly agree that the First World War marked the end of the Progressive movement (see Hofstadter 1955). Therefore, it is unlikely that the civil service reformers were able to mobilize in several states, let alone do so at periodic intervals (and several decades apart at that) over a fifty-seven year span (1883-1940).

While the popular descriptive and prescriptive accounts of state civil service reform have long deserved empirical scrutiny, a survey of the existing literature reveals but a single empirical analysis of the roots of state merit systems (see Dresang 1982). Dresang utilizes information culled from a survey instrument administered to agencies that were responsible for personnel management in all fifty state governments to develop a score of contemporary reform activities that he compares with Walker's innovation score (see Walker 1969). Using only bivariate comparisons Dresang hypothesizes that gubernatorial conflict may have been the primary force driving state merit adoptions. However, 
Dresang's analysis does not warrant this conclusion because he offers no causal evidence that links party competition with either the presence or the absence of state merit systems. Moreover, with bivariate analysis one cannot discern the valid influence of other plausible correlates of reform. In sum, one empirical question remains largely unexplored: Why did states adopt merit reform when they did? Our study breaks important new ground by bringing multivariate methods of analysis to bear upon an important phase in American state bureaucracy.

\section{MODELING PATRONAGE'S SURVIVAL: ISSUES OF RESEARCH DESIGN AND ANALYSIS}

Reform rarely diffuses rapidly or uniformly across the population of potential adopters; thus proper analysis of diffusion phenomena requires a dynamic research design. Our explanatory focus is on the following question: What factors led some states to establish merit systems as early as 1912 while other states did not do so until the late 1930s? If a combination of state-specific and national factors fueled merit adoptions, it follows that a priori we ought to expect that neither will all states establish a merit system nor will all adopting states do so at the same time. Rather, at any given time, the causal conditions are likely to vary across the states so that while some state personnel systems undergo change, others do not. In short, governmental reform is not an abrupt, all-powerful wave that touches all governments in its path; rather it is a phenomenon with marked spatial and temporal overtones (see Figure 1).

We rely on duration models to analyze state merit adoptions precisely because these models allow us to take into account the spatial and temporal nature of reform (Vermunt 1997; Box-Steffensmeier and Jones 1997). Specifically, we estimate a survival model in which the event of interest is failure - merit adoption - and the goal is to determine if and how the specified set of causal factors increase or decrease the transition rate from survival to failure. Our dependent variable is the length of time a state survives, or stays with the status quo, before adopting a merit system. For each state in our data set, we construct a duration measure by utilizing information on the year of adoption of a merit system as reported in a census of civil service agencies in the United States and Canada. The report was conducted by the Civil Service Assembly of the United States in 1937 and 1940. ${ }^{7}$

The Assembly recognizes a merit system as in effect if the state meets either of the following conditions: if it maintains a central personnel agency established by formal legal provisions which, among its other functions, administers a merit system of appointments based on open competitive examinations; or if it operates under a formal merit system that includes the use of open competitive examinations in making appointments, administered by the personnel agency of another jurisdiction. ${ }^{8}$ We supplement this information with data gleaned from various published census and other reports. In particular, we rely on Hofferbert's (1992) study, which contains electoral, demographic, and other relevant data for fortyeight states at decennial points from 1890 to 1960, as well as Historical Statistics of the United States (1975). By necessity, we recover intercensal estimates via linear interpolation, a solution common to event history analysis (see Warwick 1992a and b).

We restrict our empirical focus to merit adoptions that occurred between 1900 and

7 Duration is measured as $t_{i}-1883$ where $t_{i}$ is the year of merit adoption for state $i$.

8 See Civil Service Assembly of the United States and Canada (1940, 6-7) for additional details. 
1939 in forty-six states; we exclude Alaska and Hawaii because both received statehood well after merit systems became mandatory. Our focus is strictly on endogenous (i.e., voluntary) rather than exogenous (i.e., mandatory) merit adoptions. We also exclude New York because it, in conjunction with the Pendleton Act, is essentially responsible for the innovation of the merit system in the United States per se, and thus it serves as the primary impetus for the merit reform movement. Finally, confusion in the literature over Massachusetts' adoption date forces us to exclude Massachusetts from the analysis. ${ }^{9}$ In the next section, we will comment on three conventional explanations for the rise and diffusion of state merit reforms and then introduce our theoretically motivated causal explanation and formulate the specific hypotheses that we test in our analysis.

\section{THE DYNAMICS OF STATE MERIT REFORM}

Historical accounts of the Progressive Era often portray the shift to merit as a moral crusade (see, for example, Hoogenboom 1958-59 and 1968; Van Riper 1958; McDiarmid 1946; A. H. Aronson 1940; Wheeler 1919). Civic reformers, scholars argue, trumped corrupt politicians who traditionally relied on patronage to improve their (and their party's) chances of reelection and continued access to spoils (A. H. Aronson 1940). To be sure, while the influence of political culture and good government sentiments is not altogether implausible, this hypothesis cannot explain why some states adopted early while others did so decades later - unless civic reformers emerged in different states at different times. In fact, the very scholars who support conventional portrayals of merit reform also agree that civic reformers disbanded quickly after passage of the Pendleton Act in 1883. For example, according to Hoogenboom (1968, 259-65):

[After] 1895, the civil service reform movement continued to languish. Reformers bickered among themselves. . . . Reformers even disagreed over methods of reform. . . Not only did membership of [state civil service reform] associations decline, but entire associations collapsed as well. In December 1883, there were fifty-nine civil service reform associations; nine years later there were but thirty-five.

The short-lived nature of the reformist sentiment ought to come as no surprise to those who study collective action problems. We know that interest groups are not only difficult to manufacture and sustain, but that mobilizing individuals in support of or in opposition to reform is tricky as well (Olson 1965). If the unity and numerical strength of civil service reform associations did not last beyond the 1890 s, it is difficult to comprehend how the merit adoptions that took place in the twentieth century could be the handiwork of these groups.

That the establishment of the federal civil service also fails on many counts to reflect the imprimatur of reformist sentiments further questions the validity of the good government thesis (see, for example, Johnson and Libecap 1994; Kernell and McDonald 1999). Johnson and Libecap, for example, argue that in creating the federal civil service system the president and the Congress were jointly benefiting from the concomitant reduction in the costs

9 It is important to note that to initiate an analysis several years after the subject (here a state) first becomes at risk normally poses the problem of sample selection. In our case, to ignore the fact that our sample does not include two innovator states would yield biased estimates. However, we successfully tackle the sample selection issue in our analysis by taking into account the length of time that has lapsed before the start of our observation period (i.e., 1900) and thereby recovering unbiased estimates (see Vermunt 1997 and Guang 1993 for details). 
associated with struggles for control of the public bureaucracy. Because the Constitution granted neither the president nor the Congress unmitigated and clear control of the federal bureaucracy, and because informal agreements are invariably unstable and unenforceable, formalized arrangements that insulate the bureaucracy are mutually preferable (see North 1990). Kernell and McDonald offer a different argument: The new breed of office-holding politicians who entered Congress at the end of the nineteenth century saw greater electoral payoffs from providing direct services to their constituencies than from subsidizing local party organizations. Thus they eschewed patronage for the merit system.

While interbranch struggles for control of an expanding bureaucracy may have fueled passage of the Pendleton Act, it is doubtful that a similar dynamic also applied at the state level. Particular features of the state governmental landscape call the interbranch hypothesis into question. Specifically, because for the most part state chief executives did not acquire meaningful powers until long after the Great Depression, it is unlikely that gubernatoriallegislative struggles over the state public bureaucracy were responsible for state merit adoptions (see, for example, Bowman and Kearney 1996; Adrian and Fine 1991). However, party competition and state-local conflict have been suggested as possible causes of state merit adoptions (see Teaford 1983; Johnson and Libecap 1994; Dresang 1982). Essentially, scholars have argued that politicians in one-party states saw little reason to abandon patronage. However, politicians who faced stiff electoral competition, particularly in the gubernatorial races, recognized the benefits of blanketing public-sector employees. We test for these hypothesized effects of competitiveness by incorporating in our models the vote margin between the winner and the runner-up in the gubernatorial race. ${ }^{10}$ Specifically, we hypothesize that incumbents in states with heightened levels of electoral competition reaped relatively greater benefits by minimizing the potential for use of patronage-based electoral strategies. ${ }^{11}$ The best means of formally inhibiting patronage politics was via the merit system. Thus, politicians in states with greater electoral competition ought to have been more likely to opt for the merit systems than their counterparts in less competitive states.

However, we also believe certain environmental conditions mediated politicians' incentives for establishing the merit system. For instance, politicians in states with a relatively larger influx of traditional patronage constituencies were likely to be more concerned about meeting patronage demands. In particular, these politicians most likely realized the potential consequences of excluding new immigrants from their electoral coalitions: the defection of these groups to their challengers. ${ }^{12}$ Certainly, much research on urban political dynamics exemplifies the dilemma local politicians faced, not only with every immigration wave but also with the migration of blacks from the South (see, for example, Boulay and DiGaetano 1985). We hypothesize that the likelihood of merit adoptions will be relatively greater for competitive states facing greater inflows of foreign-born whites than for competitive states facing negligible inflows. We test for these dynamics by including a measure of the proportion of foreign-born migrants to the state (foreign-born), and by con-

10 While we initially considered utilizing Hofferbert's (1992) Index of Competitiveness of Elections, we abandoned this strategy because of significant missing data. We assign to the interelection years the vote margins in the preceding gubernatorial election.

11 Aldrich (1995) and Horn (1995) also suggest that in preventing spoils politicians reap other benefits: Incumbents can insulate their preferred policy agendas and programs from possible interference by future regimes.

12 It may seem curious that challengers could successfully mount a credible challenge using, among other things, the offer of patronage, although patronage would not accrue until they actually secured public office. However, party machines were able to engage in ex ante quid pro quo because their formal structure facilitated coordination (Pizza 1994). 
structing a suitable interaction variable (competitiveness $*$ foreign-born). ${ }^{13}$ We also include state population size (population size) as a control for baseline differences in the size of the electoral market.

Irrespective of electoral competition and migratory patterns of patronage constituencies, however, politicians could have shirked demands for patronage if the state electoral machinery was laboring under the secret ballot. The Australian ballot reduced turnout rates, especially among the poor (see Heckelman 1995 and 2000). In addition, by nullifying implicit vote contracts the secret ballot led to a decrease in the incidence of candidates who offered pecuniary rewards in exchange for votes (Hecklemann 2000, p. 195). Hypothesizing that the overall incentive for opting out of patronage is likely to be considerably reduced under the Australian ballot, we include a dummy variable (secret ballot) that measures whether or not the state employs the secret ballot ( 1 if secret ballot; 0 otherwise). ${ }^{14}$

In addition to the electoral landscape, we believe state-local politics strongly influenced merit adoptions. Specifically, historians maintain that state-local relations were rarely, if ever, harmonious because state legislatures tended to be dominated by rural rather than by urban interests (see, for example, Wiebe 1967; Griffith 1974a and b; Erie 1988; but see also Teaford 1983; Monkkonen 1984 and 1988). For instance Burns and Gamm (1997, p. 59) note that "[d]uring the Progressive Era, activists regularly criticized the ways in which rural-dominated state legislatures imposed hostile charters and statutes on big cities, and accounts of rural and partisan legislative hostility to cities permeate twentieth-century state and local politics." This urban hostility was fueled by partisan concerns over spoils predominantly concentrated in large cities. Hence we suspect that as the degree of urbanization of a state increases, so will the potential for urban-rural conflict. We incorporate this dynamic in our models by measuring the proportion of state population living in urban areas (urbanization).

Finally, we also believe that the state economic climate influenced that adoption of merit reform. In particular, we expect fluctuations in the overall health of the state economy to influence merit adoptions in two ways. First, we hypothesize that a struggling economy places additional pressures for public assistance programs, as was the case following the Great Depression, making more desirable the call to place all state and local employees of federally funded welfare programs under the merit system. However, a struggling economy may also engender increased demands for patronage, which in an era of dwindling spoils magnifies the incentives for state politicians to adopt the merit system. While different dynamics are at work here, both lead to the same result: the increased likelihood of merit adoption. While our data prevent us from distinguishing between these dynamics, we nevertheless allow for the general effect of a floundering state economy by modeling the proportion of commercial and business failures in the state per year (business failures). ${ }^{15}$ Again, in order to explore the possibility that competitive states were more likely to respond to both urban and economic pressures than were states with marginal levels of political competition, we specify suitable interaction variables (competitiveness * urbanization) and (competitiveness $*$ business failures). In Table 1 we report the description statistics of our empirical measures.

\footnotetext{
13 We are thankful to an anonymous referee for suggesting various measurement possibilities.

14 Secret ballot data are courtesy Lott and Kenny (1999).

15 Relative growth in gross state product (GSP), and changes in annual state personal income, would be reasonable alternative indicators of the vitality of the state economy. However, GSP data do not exist for the pre-1977 period, and annual state personal income data are unavailable for the pre-1929 period.
} 


\section{Figure 2}

Regional Receptivity to Reform in the States Nelson-Aalen

Cumulative Hazard Estimates (by Region)

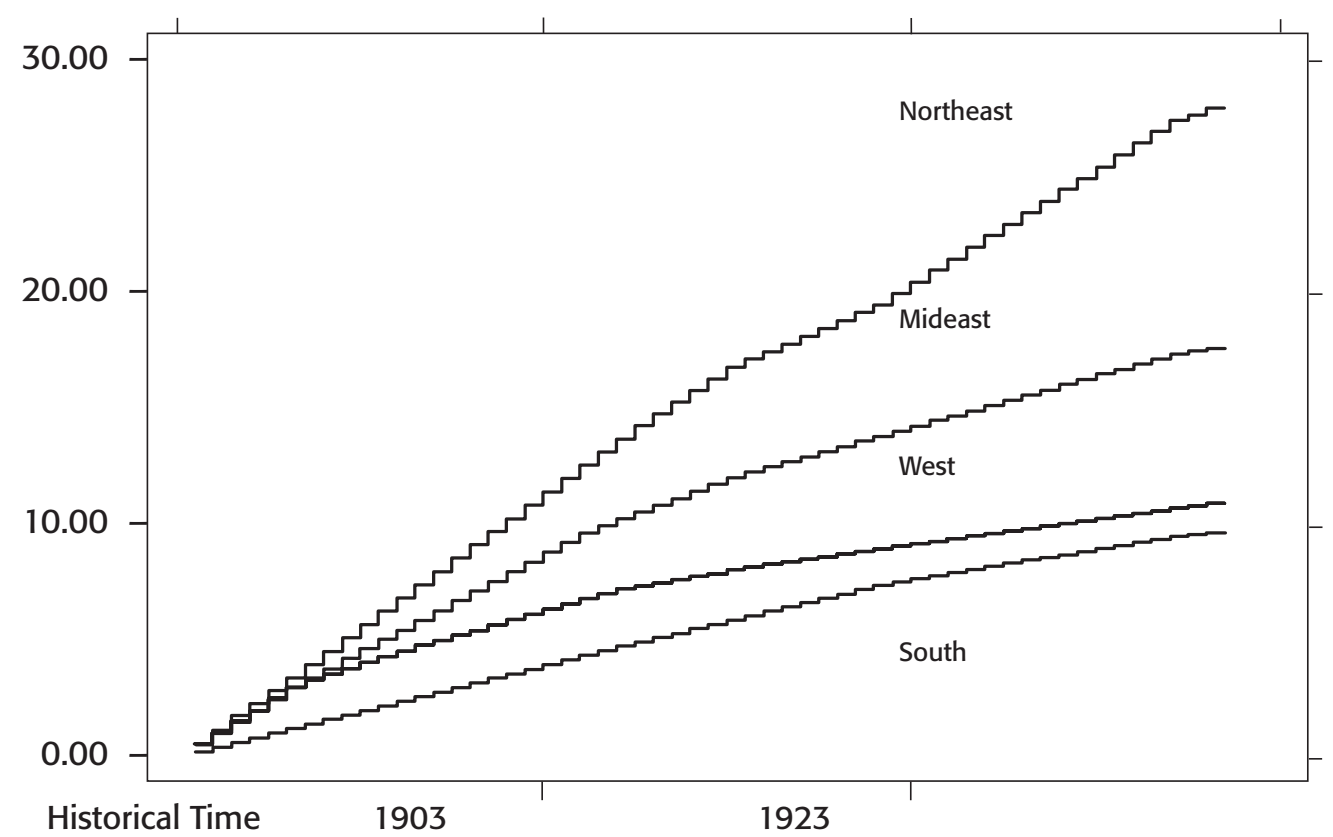

\section{FINDINGS}

Considerable research has argued for regional variation in receptivity to reform (see Shefter 1983; Bridges 1992 and 1997). Accordingly, we initiate our inquiry by testing for differences in the rate of reform across the Northeast, the Midwest, the South, and the West. As is evident in Figure 2, disaggregating the rate of reform by region suggests that while states in the Northeast were most likely, states in the South were the least likely to adopt merit systems. ${ }^{16}$ Analyzing the equality of survivor functions by way of the Wilcoxon (Breslow) test and the Log-Rank test yields a similar conclusion: The respective test statistics are significant at better than the 0.0001 level. ${ }^{17}$ It remains to be seen, however, whether these naïve regional differences - that is, differences explained without recourse to any causal variables - in merit activity remain significant in a multivariate setting. Accordingly, in our multivariate analysis we test for regional influences by including, in addition to the variables discussed in the preceding section, a set of dummy variables pertaining to specific regions Northeast, South, and West. ${ }^{18}$

We initiate our multivariate analysis by examining the Nelson-Aalen cumulative hazard function for the forty-six states that had not adopted merit systems as of 1900 (see Figure 3). Essentially, the cumulative hazard rate denotes the likelihood of merit adoption in successive time intervals, given that the state failed to adopt in the preceding time interval.

\footnotetext{
16 The graph depicts survivor functions estimated for each region.

$17 \quad \chi^{2}(3)=104.84$ and $\chi^{2}(3)=106.36$ respectively.

18 Midwest is the excluded category.
} 


\section{Figure 3}

Nelson-Aalen Cumulative Hazard Estimate (95 percent Pointwise Confidence Interval Band Shown)

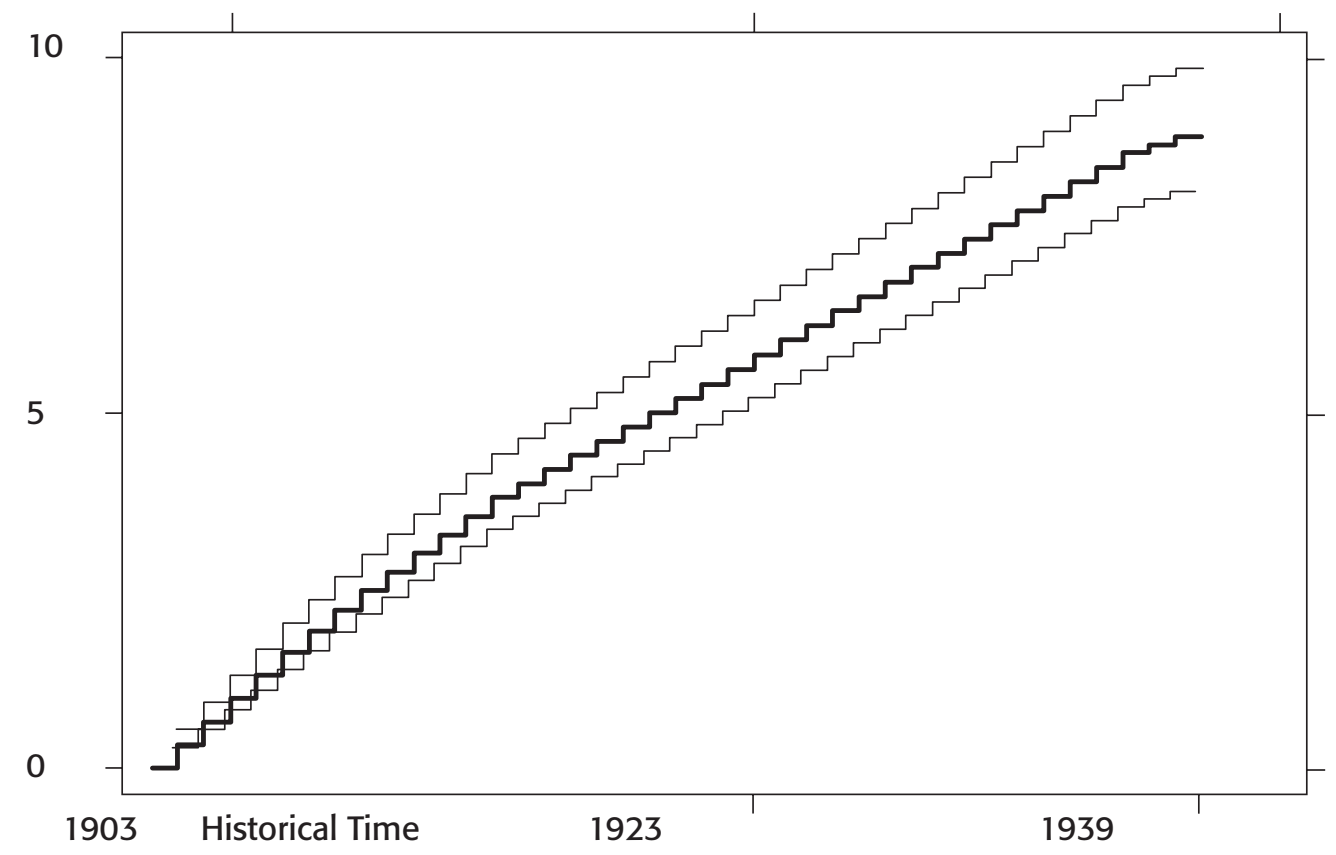

It is cumulative in that its value is the total of the hazard up to each time interval. The shape evident in Figure 3 suggests that the rate of merit adoptions increased over time. While several distributions (for example, the Gompertz, log-logistic, Weibull) might reasonably approximate such a pattern, in Table 2, we report the results obtained from postulating that the Weibull distribution adequately characterizes the temporal dimension of merit adoptions. ${ }^{19}$ Overall, the results substantiate our claim that political dynamics played a far more significant role in state merit adoptions than has been recognized. We will now undertake a detailed discussion of our empirical findings.

We find, for example, a substantial difference in the rate of merit adoptions for states with low levels of political competition as compared to states with high levels of competition (defined as states with competitiveness scores one standard deviation above the mean). In particular, states with high levels of political competition have a transition rate 230 percent higher than do states with average degrees of competition. ${ }^{20}$ While states that experience larger inflows of foreign-born white immigrants also reflect higher transition rates to merit systems, the impact is far more conservative; a one standard deviation increase in these immigrant flows only raises the transition rate by one-half percent. However, the net impact of immigration flows is far greater in competitive environments: Holding electoral competition at its mean level, a one standard deviation increase in foreign-born white immigrants raises the transition rate by an additional 2 percent.

19 We also analyze our models using alternative Gompertz and Exponential distributions, respectively. While the coefficients are strikingly similar, the Weibull is preferred on the basis of the Akaike information criterion (AIC).

20 The impact of a discrete change in a continuous variable on the transition rate is measured as $\exp \left(\beta^{*} \delta\right)$ where $\delta$ is the discrete change in the continuous variable. 
Table 1

Descriptive Statistics, State Merit Adoptions, 1900-1939

\begin{tabular}{lc}
\hline Variable & Mean (Std. Dev.) \\
\hline Competitiveness & $73.90(29.30)$ \\
Urbanization & $33.25(18.27)$ \\
Foreign born & $0.18(4.87)$ \\
Secret ballot & $0.75(0.43)$ \\
Business failures & $44.43(28.99)$ \\
Population size & $50.23(81.82)$ \\
Median duration & 40 \\
\hline
\end{tabular}

We also argue that the use of the Australian ballot probably served as a safety valve in terms of allowing state politicians to eschew the switch to merit by ignoring heightened demands for spoils. Irrespective of electoral competition and migratory patterns of patronage constituencies, the Australian ballot uniformly reduced turnout rates, especially among the poor, nullifying implicit vote contracts in force (Heckelman 1995 and 2000). Therefore, it is hardly surprising that we find states that rely on the secret ballot are significantly less likely to adopt merit systems than are states without the secret ballot. Specifically, we find states that use the Australian ballot reflect transition rates that are lower by almost 57 percent. ${ }^{21}$

In the historical literature much has been made of regional variation in receptivity to reform (see, for example, Shefter 1983; Bridges 1997). However, relative to Midwestern states, we find evidence of regional effects only for states in the West. Specifically, the transition rate for the Midwestern states is twice that of Western states.

We also find that the passage of historical time significantly influences the likelihood of state civil service reform in a unique and intriguing manner. In particular, the significance and size of the shape parameter suggests that the transition rate increases over time, all else being equal. While this is not an uncommon finding when juxtaposed against the $S$-shaped curve so often remarked upon in the diffusion of policy innovations literature, students of institutionalism will be surprised to note that environmental factors can at times counter the presumed tendency of institutions to reinforce stasis over time. In the case of state merit systems, for example, the cost-benefit calculus politicians faced when choosing between patronage and merit was the pivotal factor disrupting stasis. Environmental dynamics (especially an increase in patronage constituencies), worsening state economies that forced citizens to turn to the government for pecuniary sustenance, and increasing urbanization tipped the scales in favor of merit adoption. Moreover, although politicians could have shirked patronage demands insofar as the state employed the Australian ballot and thus eschewed merit system adoptions, the secret ballot appears to have provided less than satisfactory refuge. Political competition was the catalyst in the shift to merit. In particular, politicians were most likely to respond to environmental shifts when they faced stiffer political competition than when such electoral pressures were absent.

\section{CONCLUSIONS}

Typically, new institutionalists argue that actors embedded in older institutions are less able to effect changes to the status quo because institutions, technologies, ideologies, and pub- 
Table 2

Weibull Estimates, State Merit Adoptions, 1900-1939

\begin{tabular}{lc}
\hline Variable & Coefficient \\
\hline Competitiveness & 0.0172 \\
& $(0.0080)^{*}$ \\
Urbanization & 0.0285 \\
& $(0.0158)$ \\
Foreign born & 0.0013 \\
& $(0.0005)^{*}$ \\
Secret ballot & -0.5670 \\
& $(0.1954)^{* *}$ \\
Business failures & 0.0117 \\
Population size & $(0.0109)$ \\
& 0.0061 \\
Competitiveness * foreign born & $(0.0007)$ \\
& 0.0004 \\
Competitiveness * secret ballot & $(0.0001)^{*}$ \\
Competitiveness * business failures & -0.0001 \\
& $(0.0001)$ \\
Northeast & -0.0000 \\
South & $(0.0001)$ \\
West & -0.2764 \\
Shape parameter & $(0.1885)$ \\
Constant & -0.0613 \\
& $(0.1691)$ \\
& -0.6918 \\
& $(0.1995)^{* *}$ \\
& 0.6385 \\
& $(0.1720)^{* *}$ \\
& -1.6067 \\
& $(1.0718)$ \\
\hline
\end{tabular}

Note: Number of subjects $=46$; number of observations $=1,578 ; \mathrm{LL}=450.6206 ; \chi^{2}(12)=180.52 * *$.

$* \mathrm{p}<0.05 . * * \mathrm{p}<0.01$. Standard errors in parentheses.

lic policies often exhibit the properties of path dependency and lock-in (see Arthur 1994; Alston, Eggertsson, and North 1996; and North 1990). Recently, Woodlief (1998) has extended to urban politics this notion that random perturbations early in the history of policy or institutional choice, together with the self-reinforcing properties of these choices, shape subsequent outcomes. Woodlief's principal argument is that "cities with similar initial characteristics or that are facing a similar crisis (e.g., the Great Depression) may evolve differently because of underlying differences. ... [Thus] context is important because it encompasses the cumulative effects of history" (p. 427). We suspect the regional effects we discern for the Midwest and the West reflect some of the dynamics of path dependency. However, that the likelihood of merit reform increases over time, net of all other forces we have specified, suggests that the larger context mediates, given suitable conditions, the inherent propensity for lock-in commonly ascribed to institutions as they age.

In the case of state merit reform, for example, while the Pendleton Act had already curtailed the federal spoils base, and subsequent extensions of merit coverage only served to shrink this base, the Great Depression greatly affected the nation's economic health. While 
state governments were facing rapidly dwindling abilities to create programs that might allow politicians to indulge in patronage, the swelling ranks of the unemployed could have only intensified pressures for patronage. The grim economic situation of the 1930s may well have been the catalyst that prompted laggard states to push through state merit reform.

Yet this national dynamic does not minimize the role political expediency essayed in state merit reform of the early twentieth century. Early twentieth century politicians were able to co-opt the merit principle with relative ease and remarkable guile (see Hoogenboom 1961). Reform is politics because changes in governing arrangements invariably shuffle the stack of winners and losers. That merit reform ultimately, as we now know, proved ineffective in completely eliminating patronage politics only emphasizes the ability of politicians to manipulate an idea in good currency. Somehow extant discussions of merit reform in the states tend to downplay the staggered pattern of state merit reform, suggesting that reform diffused rapidly and uniformly across states shortly after passage of the Pendleton Act in 1883 .

By no means do we suggest that the Progressive Era and the good government movement had no bearing upon the civil service question in the United States. However, as we argue and as we demonstrate in this study, an explicit political calculus largely motivated by state and national economic and demographic shifts within and across states largely drove state adoptions of the merit principle. Explicit recognition of this political calculus enables a more comprehensive understanding than we have had of why states adopted the merit principle at the times they did.

\section{REFERENCES}

Adrian, Charles R., and Fine, Michael R. 1991. State and Local Politics. Chicago: Nelson-Hall.

Aldrich, John H. 1995. Why Parties? The Origin and Transformation of Party Politics in America. Chicago: University of Chicago Press.

Alston, Lee; Eggertsson, Thrainn; and North, Douglass. 1996. Empirical Studies in Institutional Change. New York: Cambridge University Press.

Anderson, William, and Weidner, Edward. 1951. State and Local Government in the United States. New York: Henry Holt.

Aronson, Albert H. 1940. "Merit Systems Under the Social Security Act." Public Personnel Review 1: $24-28$.

- 1974. "State and Local Personnel Administration." In Biography of an Ideal, United States Civil Service Commission. Washington D.C.: Government Printing Office.

Aronson, Sidney H. 1964. Status and Kinship in the Higher Civil Service: Standards of Selection in the Administrations of John Adams, Thomas Jefferson, and Andrew Jackson. Cambridge, Mass.: Harvard University Press.

Arthur, W. Brian. 1994. Increasing Returns and Path Dependence in the Economy. Ann Arbor: University of Michigan Press.

Barrilleaux, Charles. 1999. "Statehouse Bureaucracy: Institutional Consistency in a Changing Environment." In Ronald Weber and Paul Brace, eds. American State and Local Politics: Directions for the 21st Century. New York: Chatham House.

Baruch, Ismar. 1942. Position-Classification in the Public Service. Chicago: Civil Service Assembly.

Boulay, Harvey, and DiGaetano, Alan. 1985. "Why Did Political Machines Disappear?" Journal of Urban History 12: 1: 25-49.

Bowman, Ann O., and Kennedy, Richard C. 1996 State and Local Government. Boston: HoughtonMifflin.

Box-Steffensmeier, Janet, and Jones, Bradford. 1997. "Time Is of the Essence: Event History Models in Political Science." American Journal of Political Science 41: 1414-61. 
Bridges, Amy. 1992. "Winning the West to Municipal Reform.” Urban Affairs Quarterly 27: 4: 494-518.

-1997. Morning Glories: Municipal Reform in the Southwest. Princeton, N.J.: Princeton University Press.

Burnham, Walter Dean. 1992. Partisan Division of American State Governments, 1834-1985. [Computer file]. Conducted by Massachusetts Institute of Technology. ICPSR ed. Ann Arbor, Mich.: Interuniversity Consortium for Political and Social Research.

Burns, Nancy, and Gamm, Gerald. 1997. "Creatures of the State: State Politics and Local Government, 1871-1921." Urban Affairs Review 33: 59-96.

Cayer, N. Joseph. 1986. Public Personnel Management in the United States. New York: St. Martin's. . 1995. "Local Government Personnel Structure and Policies." Municipal Year Book. Washington, D.C.: International City/County Management Association.

Civil Service Assembly of the United States and Canada. 1940. Civil Service Agencies in the United States - A 1940 Census. CSA Pamphlet No 16.

Civil Service Assembly of the United States and Canada. 1943. Civil Service Agencies in the United States - A 1943 Supplement. CSA Pamphlet No 16-A.

Conover, Milton. 1925. "Merit Systems of Civil Service in the United States." American Political Science Review 19: 544-60.

Devlin, Thomas. 1896. Municipal Reform in the United States. New York: Putnam.

Dresang, Dennis. 1982. "Diffusion of Civil Service Reform: The Federal and State Governments." Review of Public Personnel Administration 2: 35-44.

Dye, Thomas R. 2000. Politics in States and Communities. Upper Saddle River, N.J.: Prentice Hall.

Erie, Stephen. 1988. Rainbow's End. Berkeley: University of California Press.

Fish, Carl. 1920. Civil Service and Patronage. Cambridge, Mass.: Harvard University Press.

Graves, W. Brook. 1953. American State Government. Boston: Heath.

Gray, Virginia, and Eisinger, Peter. 1997. American States and Cities. New York: Addison-Wesley.

Griffith, Ernest S. 1974a. A History of American City Government: The Conspicuous Failure, 1780-1900. New York: Praeger.

- 1974b. A History of American City Government: The Progressive Years and Their Aftermath, 1900-1920. New York: Praeger.

Guang, Guo. 1993. “Event-History Analysis for Left-Truncated Data.” In Peter V. Marsden, ed. Sociological Methodology. Washington, D.C.: Blackwell.

Hays, Steven, and Reeves, Zane. 1984. Public Personnel Management in the Public Sector. Boston: Allyn and Bacon.

Heckelman, Jac C. 1995. "The Effect of the Secret Ballot on Voter Turnout Rates." Public Choice 82(Jan.): 107-24.

- 2000. "Revisiting the Relationship Between Secret Ballots and Turnout: A New Test of Two Legal-Institutional Theories.” American Politics Quarterly 28: 2: 194-215.

Hofferbert, Richard I. 1992. Socio-economic, Public Policy and Political Data for the United States, 1890-1960. [Computer file]. Conducted by Cornell University Center for International Studies. ICPSR ed. Ann Arbor, Mich.: Inter-university Consortium for Political and Social Research.

Hofstadter, Richard I. 1955. The Age of Reform. New York: Random House.

Hoogenboom, Ari. 1958-59. "The Pendleton Act and the Civil Service." American Historical Review 64: 301-18.

. 1961. Outlawing the Spoils: A History of the Civil Service Reform Movement: 1856-1883. Urbana: University of Illinois Press.

Horn, Murray J. 1995. The Political Economy of Public Administration: Institutional Choice in the Public Sector. New York: Cambridge University Press.

Hosmer, David W., Jr., and Lemeshow, Stanley. 1999. Applied Survival Analysis: Regression Modeling of Time to Event Data. New York: Wiley.

Johnson, Ronald, and Libecap, Gary. 1994. The Federal Civil Service System and the Problem of Bureaucracy. Chicago: University of Chicago Press.

Kernell, Samuel, and McDonald, Michael P. 1999. "Congress and America's Political Development: The Transformation of the Post Office from Patronage to Service." American Journal of Political Science 43: 3: 792-811. 
Lambert, Henry. 1885. The Progress of Civil Service Reform in the United States. Boston.

Lott, John R., and Kenny, Lawrence W. 1999. "Did Women's Suffrage Change the Size and Scope of Government?" Journal of Political Economy 107: 6-1: 1163-98.

Maranto, Robert. 1998. "Thinking the Unthinkable in Public Administration: A Case for Spoils in the Federal Bureaucracy." Administration and Society 29: 633.

McCurdy, Arthur. 1998. "Political Culture, Local Government and Progressive Personnel Practices: The Case of Collective Bargaining Provisions and a Test of Elazar's and Lieske's Measures of Political Culture." Review of Public Personnel Administration (winter) 18: 23-38.

McDiarmid, John. 1946. "The Changing Role of the U. S. Civil Service Commission." American Political Science Review 40: 1067-96.

Monkkonen, Eric. 1984. "The Politics of Municipal Indebtedness and Default, 1850-1936." In T. McDonald and S. K. Ward, eds. The Politics of Urban Fiscal Policy, pp. 125-60. Beverly Hills, Calif.: Sage. - 1988. America Becomes Urban. The Development of U. S. Cities and Towns, 1780-1980. Berkeley: University of California Press.

National Civil Service Reform League. 1937. The Civil Service in Modern Government: A Study of the Merit System. New York: National Civil Service Reform League.

North, Douglass. 1990. Institutions, Institutional Change, and Economic Performance. New York: Cambridge University Press.

Olson, Mancur. 1965. The Logic of Collective Action: Public Goods and the Theory of Clubs. Cambridge, Mass.: Harvard University Press.

Pizza, David Anthony. 1994. "Structure and Cooperation in Party Politics: The Development of Urban Party Organizations in the United States, 1896-1930.” Ph.D. diss. University of Chicago.

Rosenbloom, David. 1989. Public Administration: Understanding Management, Politics, and Law in the Public Sector. New York: McGraw-Hill.

Schultz, David A., and Maranto, Robert. 1998. The Politics of Civil Service Reform. New York: Peter Lang.

Shefter, Martin. 1983. "Regional Receptivity to Reform: The Legacy of the Progressive Era." Political Science Quarterly 98: 459-83.

Stewart, Frank. 1929. The National Civil Service Reform League. Austin: University of Texas Press.

Teaford, John. 1983. The Unheralded Triumph: City Government in America, 1870-1900. Baltimore: Johns Hopkins University Press.

U.S. Bureau of the Census. 1975. Historical Statistics of the United States: Colonial Times to 1970. Washington, D.C.: Government Printing Office.

Van Riper, Paul. 1958. History of the United States Civil Service. Evanston, Ill.: Row, Peterson.

Vermunt, Jeroen K. 1997. Log-Linear Models for Event Histories. Thousand Oaks, Calif.: Sage.

Walker, Jack L. 1969. "The Diffusion of Innovations Among the American States." American Political Science Review 63: 880-99.

Warick, Paul V. 1992a. "Economic Trends and Government Survival in Western European Parliamentary Democracies." American Political Science Review 86: 875-87.

_. 1992b. "Rising Hazards: An Underlying Dynamic of Parliamentary Government." American Journal of Political Science 86: 857-76.

Wheeler, Everett. 1919. "The Rise and Progress of the Merit System." Political Science Quarterly 34: 486-92.

Wiebe, Robert. 1967. The Search for Order, 1877-1920. New York: Hill and Wang.

Woodlief, Anthony. 1998. "The Path-Dependent City." Urban Affairs Review 33: 405-37. 